\title{
SOCIAL MEANING \\ OF MANGARA BANUA TONGKONAN CEREMONY IN TORAJA SOCIETY
}

\author{
Sam'un Mukramin, Lukman Ismail \\ Department of Sociology Education \\ University of Muhammadiyah Makassar \\ sam'un.mukramin@unismuh.ac.id
}

\begin{abstract}
As the background of this research, there was an existence of a mismatch between idealism and reality. Social change that lead to a negative change of Westernization or a change that lead to cultural destruction, but in reality therewere many cultures that had been preserved. In this case, the researchers studied the local culture that existed until now. For example, Mangrara Banua Tongkonan ceremony, the researchers saw that only the major of young generation in Tanah Toraja people knew specifically the meaning of Mangrara Banua Tongkonan Ceremony.

The type of research was descriptive qualitative research that a method in research the status of community, an object, an event. The location of this research was conducted in Ariang Village, Makale Sub-district, Tana Toraja Regency, with data collection technique were observation and interview with respondents. The results obtained about the meaning of social Mangrara Banua Tongkonan ceremony in Tana Torajawas analyzed descriptively qualitative, it can be concluded that the cause of Mangrara Banua Tongkonan ceremony was still preserved until now because of the value, tradition and the active participation of the community. While the meaning in Mangrara BanuaTongkonan ceremony was connotative and denotative meanings.
\end{abstract}

Keywords: society, culture, and Mangrara Banua

\section{INTRODUCTION}

One of the cultures in Indonesia that is highly admired is the culture of Tana Toraja community that existed and continuesly become a tourist destination both from abroad and within the country. The uniqueness of Tana Toraja culture is much admired by societyis the tradition of Mangrara Banua Tongkonan ceremony which always in waiting for the celebrated by the community. Sam'un Mukramin (2015: 417), Limitations of ability or knowledge create man to do the job because its result not on its process, vice versa. And lot human humans in the work does not expect the process will but the results that become the main goal in working.

These results show the efforts of the Tana Toraja community in the preservation of Mangrara Banua Tongkonan ceremony 
by holding ceremonies where every society who build a Tongkonan house or during replacement ceremony for roof and pole. The ceremony is done with existinga rousing variety of rituals. And all the local people participated in the ceremony and participated in enlivening. Participation that can be given by the community in a cultural eventare money participation, social participation, participation in decision-making process, and representative participation. Participation of money if every Mangrara Banua Tongkonan ceremonycan spend a lot of money. So loyal people should give each other donations in the form of money or donate livestock such as pigs and buffalo when Mangra Banua Tongkonan.

Participation of energy can be seen in the case of community participation in performing the ceremony can be seen when performing animal slaughter. They parade in a way to form a circle and the traditional music and dance as well as singing TanaToraja typical songs. In addition, there is also social participation, such as attending the ceremony of death and the inauguration ceremony of Tongkonan house in the form of donation of attention or sign of proximity in order to motivate others in participating. Participation in the community is influenced by factors such as education, employment, income, stay length, climate, economy, culture, schools and communities and nations is benefit and encourage the growth and development of public participation in preserving this culture.

Governments and communities should work together in preserving the culture and mantainthe uniqueness of culture and be admired by society. In addition, the objectives to be achieved by the community should be assisted by the norms and punishment against values and norms. Like when there are people who do not participate in enliven the ceremony event it will be ostracized by the community because it is not participated in terms of togetherness. If there is a violation of the values and rules that have been determine then will be ostracized.

Parsons (Sztompka, 2011), believes that the development of society is related to the development of the four main subsystem elements they are cultural (education), judiciary (integration), governance (golas acchievement), and economy (adaptation). Each subsystem is autonomous and subcollectives. In this context, the ability to adapt to the environment is a benchmark of its level of autonomy. Adaptive means increasingly high autonomy. Concretely, the higher the autonomy of each subcolective in performing its primary function in the framework of the overall of the system means the greater its ability to adapt to its environment, and this means the more advanced the community is concerned.

Traditional society is a society that upholds its ancestors and hold firm to its customs. In general, the traditional community is a society that has the perspective that carrying out the legacy of its ancestors in the form of values of life, norms, hopes, ideals, is a duty, need, and pride. Carrying out ancestral traditions means maintaining the harmony of the people, but violating the tradition means that it can harm the harmony of society. Therefore, traditional societies tend to be closed and suspicious of foreign cultural elements, as they can harm the harmony of relations among community. 


\section{REVIEW OF RELATED LITERATURES}

The approach used in this research is the structural theory of functionalism and the theory of symbolic interactionism. Consideration chooses this approach because it focuses on research or explanation on the relationship between man and his religion or belief system and culture. Therefore, to have better understanding then first explaination the theory of structural functionalism. Structural Theory of functionalism sees religion as one of the social institution that holds the key to answering the fundamental needs of society, that explained the need of human beings who cannot be satisfied with temporalvalues. Weber's see (Betty R. Scharf, 1995: 177-178) that the function of religion isasrejected of tradition or rapid change in methods and evaluation of economic activity is not possible without the incentive of morals and religion.

By that it needs awareness to maintain the preservation of local culture. Because in the community there must be a belief system or religion that is believed to each other that can strengthen the kinship system as in the Mangrara Banua Tongkonan ceremony. The ceremony is done to increase the faith of his religion and appreciate the ancestral heritage. In preserving the environment needs to approach such a sociological approach that focuses attention on the community. In this case the community serves as a keeper of culture. Society is seen as part of culture. Without society then culture will not go on the contrary.

Then the theory of symbolic interactionism, where this theory is closely related to the meanings conveyed from each ceremony performed as in the Mangrara Banua Tongkonan ceremony in Tana Toraja.
From the word interaction means people in their daily lives will always interact with other creatures, like with other social beings or the community itself or interact with animals, plants. And the importance of interacting with God and the spirit of the ancestors, as Tana Toraja people do in the Mangrara Banua Tongkonan Ceremony.

Symbolic interaction theory considers that social life is essentially human interaction using symbols that bring what they mean to communicate with each other. Symbolic Interactionism Perspective is often grouped into 2 schools (Sobur 2004; 200), namely: Chicago school by Herbert Blumer based on the teachings of Herbert Mead and Lowa and George driven by Manford $\mathrm{H}$. Kunh and Carl Couch. Although both embrace the theory of symbolic interactionism, but there are many differences of opinion between the two streams. If Blumer leads to the meaning of ediography and criticizes quantitative methodology as failing to grasp meaning, then Khun leads to the search for standardization and objectivity as well as transforming symbolic interactionism into variables (Sobur 2004; 201).

From the statement of the two ethics both discuss about human interaction with religion and belief. Based on the above theoretical studies, in the case of the implementation of Mangrara Banua Tongkonan ceremony in Tana Torajagives symbolic meaning like custom house in the form of buffalo horn as a symbol that has been held Mangrara Banua Tongkonan ceremony.

\section{RESEARCH METHODS}

According to Sugiyono qualitative method is a research method used to examine the natural objects in 
which researchers are as a key instrument. That is, research done to obtain information about the status of symptoms when the research was done or in other words researching the object of the goal naturally and the researchers are as a key instrument. Research that emphasizes events on groups, systems of thought including relationships activities, attitudes, perspective or public participation in preserving the cultural Mangrara Banua Tongkonan ceremonyin Tana Toraja. It aims to describe accurately about the facts and the relationship between the phenomena studied.

In this case the phenomenon being studied relatesto the social significance of the Mangrara Banua Tongkonan ceremony. In the field research, the researchers explored a social phenomenon that was the cause factor of preservation of Mangrara Banua Tongkonan ceremony. Researchers saw the phenomenon from observed social facts that were essentially complex. Community participation in preserving the Tongkonan Banua Mangrara ceremony involving various social strata in society required qualitative analysis that emphasized the observed facts and explored the facts behind the observed facts.

In this case, of course the facts related to the participation of the community in preserving the tradition of the Mangrara Banua Tongkonan ceremony. This research was carried out in Tana Toraja regency. Selection of the location with values and traditions that were professed by the people of Tana Toraja still thick and still maintained its uniqueness until now. And society always preserved its culture by performing various rituals that exist. This was evident from the participation of the people who still run the tradition.

\section{DISCUSSION}

Implementation of Mangrara Banua Tongkonan ceremonyin Tana Toraja had become the tradition of every citizen. Prior to the arrival of Christianity and Islam, the Torajans adopted the religion of their ancestors inherited from generation to generation. This heritage was considered as a religion and original belief known as aluktodolo. Aluk Todolo is the underlying joints of Toraja community life, including customs. Trust Aluk Todolo is believed to be as old as the first human grandmother that is Datu La Ukku'. Descendants of Datu La Ukku 'this is the first time sent on earth one of his descendants named Pong Mula $\mathrm{Au}$ who came down from the sky brought the teachings worship/message to Puang Matua.

The teaching of Aluk Todolo said that beyond the human self, there are three elements of force that are obliged to be trusted by a force that is obligatory to be trusted. The traditional ceremony of society is the embodiment of a belief system of society that has universal values that can support the national culture. This ceremony is belief and is considered sacred and sacred. Where every human activity always has a purpose and goal to be achieved, including activities that are religious. Mangrara Banua or commonly called by purifying the traditional house with animal blood is one of the traditional ceremonies that are routinely performed by the Tana Toraja people when inaugurating the house (Tongkonan) prior to the habitable.

The function of the Mangrara Banua Tongkonan Ceremony is to inaugurate the house (Tongkonan) before it is inhabited. Started by a welcome from traditional leaders, the ceremony continued with 
dances by Toraja women accompanied by drum beats. The audience from various circles both domestic and foreign tourists did not remain silent. They joined in dancing to enliven this Mangrara Buana ceremony.

In Tana Toraja society highly upholds the belief system adopted from Aluktodolo teaching which has become the tradition of every citizen. In the ceremony there are various rituals that give their own meaning.

Koentjaraningrat, (1989: 72) argues that in conducting his activities man has rules that serve as a guide in behaving, where the guidelines are culture. Culture itself is the whole system of ideas, ideas, tastes, actions and works produced by human beings in the life of society that is owned by him through learning.

The factor of the Mangrara Banua Tongkonan ceremony is still preserved until now because of the values, traditions and participation of the community, to be better understood it needs to be explained about what is the value, tradition, and participation in the preservation of this ceremony:

\section{Value}

Values are the qualities of behaviors, thoughts and characters that are considered good and righteous society that everybody deserves to imitate. In a society of value is highly esteemed and appreciated for being able to give awards and as a quality of the community self. Like those in Tana Toraja, they assume that when we appreciate the ancestral heritage by performing a ceremony of honor to the ancestors then the community is considered to have carried out its obligations and signifies the person will get the welfare of such a fortune and avoid the catastrophes.

\section{Tradition}

Tradition is a human attitudes and behaviors that have been in the process for a long time and carried out from generation to generation from ancestors. The tradition that has been entrenched will be a source in morals and virtuous person. Before explaining about the preservation of Mangrara Banua Tongkonan ceremony first explain what is meant by Mangrara Banua Tongkonan Ceremony.

The traditional ceremony of society is theembodiment of abelief system of society that has universal values that can support the national culture. This traditional law is trustworthy and is considered sacred and sacred. Where every human activity always has a purpose and goal to be achieved, including activities that are religious. MangraraBanua or commonly called by purifying the traditional house with animal blood is one of the traditional ceremonies that are routinely performed by the Tana Toraja people when inaugurating the house (Tongkonan) prior to the habitable. The function of the Mangrara Banua Tongkonan Ceremony is to inaugurate the house (Tongkonan) before it is inhabited. Started by a welcome from traditional leaders, the ceremony continued with dances by Toraja women accompanied by drum beats. The audience from various circles both domestic and foreign tourists did not remain silent. They joined in dancing to enliven this Mangrara Buana ceremony.

\section{Community Participation}

Participation is the active involvement of a person, or group of people (the community) consciously to voluntarily contribute to the development program and is involved from planning to 
implementation to the evaluation stage. The importance of participating in a community in the cultural field of a tool for knowing the conditions, needs, and the attitude of the local people, because they will know more about the project and will have a sense of belonging to the culture. What it wants to achieve in community participation is to preserve its cultureThe way of society involved in terms of implementation and decision making.

There are several forms of participation that can be given to the community in a cultural event that is money participation, social participation, participation in the decisionmaking process, and participation of representatives. Money participation is intended if every ceremony spend a lot of money. So loyal people should give each other donations in the form of money or donate livestock such as pigs and buffalo when Mangrara Banua Tongkonan ceremony is conducted.

People participations can be seen in the case of community participation in performing the ceremony can be seen when performing the slaughter of their animals paraded by shaping the circle and the traditional music and dances while singing Tana Toraja typical song. There is also social participation, such as attending the ceremony of death and the inauguration ceremony of Tongkonan house in the form of donation of attention or sign of proximity in order to motivate others in participating.

In preserving the ceremony of Mangrara Banua it is necessary for the participation of the community and awareness of the belief adopted by the society. Where their belief is the teachings of Aluk Todolo that is the teaching inherited by the ancestors who have preceded. Which if not done then the people will not live peacefully in the world and will get a disaster.

Mangrara Banua or commonly called by purifying the traditional house with animal blood is one of the traditional ceremonies that are routinely performed by the Tana Toraja people when inaugurating the house (Tongkonan) prior to the habitable. One area in South Sulawesi is still thick culture is Tana Toraja District rich in unique culture and dancing the attention of the Indonesian community and abroad. Tongkonan is basically a wooden house built by Tanah Toraja people. The wooden stage house is considered important by the people of Tana Toraja.

Furthermore, the Toraja District of Toraja which still performs the ceremony of Mangrara Banua Tongkonan is the Village of Ariang Kecamatan Makale which every execution is done with any fanfare to build Tongkonan house or when replacement of roof and pole which is attended by all residents of Ariang Village. Ceremony performed with various rituals that have their own meaning. in the Toraja tribe. Each village is a big family. Each Tongkonan has the name used as the village name. The family participates in maintaining village unity. Marriage with distant cousins (fourth cousin and so on) is a common practice that strengthens kinship ties. Toraja tribe prohibits marriage with close cousins (up to third cousins) except for nobles, to prevent the spread of property.

At first, the isolated nature of Tana Toraja formed many dialects in the Toraja language itself. After an official government in Tana Toraja, some Torajan dialects became influenced by other 
languages through the transmigration process, which was introduced since the colonial period. It is the main cause of diversity in Toraja. A prominent feature of the Torajan language is the notion of mourning death. The importance of death ceremonies in Toraja has made their language able to express feelings of grief and mourning processes at some complicated level.

The Toraja language has many terms to denote sadness, longing, depression, and mental stress. It is a catharsis for Torajans if it can clearly indicate the effect of a person's loss event; it is sometimes also aimed at reducing the suffering of grief itself.

Meaning is the relation of an object with its symbol. Meaning is basically formed based on the relationship between the symbol of communication (symbol), the human mind of the user (object). Meaning according to man's integrative ability, i.e. his senses, his powers and his mind. Man is a social being who can associate with himself, and others interpret the meanings of objects in the realm of his consciousness and decide how he acts meaningfully according to the interpretation. Even someone does something because of his social role or because of his social class or because of the history of his life.

The social meaning in the Mangrara Banua Tongkonan is a value or belief system. Given the value and belief system in the community can increase the power within the community to maintain and preserve the culture to be implemented. In addition, in every society must uphold the tradition. Where tradition is a picture of human attitudes and behaviors that have been processed in a long time and done from generation to generation starting from the ancestors. The tradition that has been entrenched will be a source in morals and virtuous person. Before explaining about the preservation of the ceremony Mangrara Banua Tongkonan first explain what is meant by Mangrara Banua Tongkonan ceremony.

The traditional ceremony of society is theembodiment of a belief system of society that has universal values that can support the national culture. This traditional law is trustworthy and is considered sacred and sacred. Where every human activity always has a purpose and goal to be achieved, including activities that are religious. Mangrara Banua or commonly called by purifying the traditional house with animal blood is one of the traditional ceremonies that are routinely performed by the Tana Toraja people when inaugurating the house (Tongkonan) prior to the habitable. The function of the Mangrara Banua Tongkonan Ceremony is to inaugurate the house (Tongkonan) before it is inhabited. Started by a welcome from traditional leaders, the ceremony continued with dances by Toraja women accompanied by drum beats. The audience from various circles both domestic and foreign tourists did not remain silent. They joined in dancing to enliven this Mangrara Banua Tongkonan ceremony.

\section{CONCLUSION}

1. Based on the results of research, factors of Mangrara Banua Tongkonan ceremony is preserved because of the value, tradition and community participation.

2. Based on the results of research the Meaning of Social Mangrara Banua Tongkonan ceremony in Tana Torajais 
the connotative and denotative meaning. Where connotative meaning is the meaning based on the sense value whereas the meaning of denotative is the meaning derived from its own actions and not based on the value of taste.

\section{BIBLIOGRAPHY}

Sam'un Mukramin. 2015. Pemulung sebagai Fenomena Sosial di TPA Sampah Tamangapa Kota Makassar. Jurnal Walasuji. Vol. 6, No. 2 Desember 2015: 413-424.

Scharf, Betty R. 1995. Kajian Sosiologi Agama. Yokyakarta: PT. Tiara Wacana Yogya.
Sobur, Alex. 2004. Semiotika Komunikasi. Bandung: Remaja Rosdakarya.

Sztompka, Piötr. 2011. Sosiologi Perubahan Sosial. (Cetakan ke-6) Jakarta: Kencana Prenada Media Group.

Sugiyono. 2013. Metode Penelitian Pendidikan: Pendekatan Kuantitatif, Kualitatif, dan RED. Bandung: Penerbit Alfabeta.

Koentjaraningrat. 1989. Kebudayaan, Mentalitas dan Pembangunan. Jakarta: Gramedia.

Budhisantoso, Subur. 1989. Tradisi Lisan Sebagai Sumber Informasi Kebudayaan dalam Analisa Kebudayaan, Jakarta: Depdikbud. 